\title{
Molecular diagnosis of Anaplasmataceae organisms in dogs with clinical and microscopical signs of ehrlichiosis
}

Diagnóstico molecular de agentes da família Anaplasmataceae em cães com sinais clínicos e microscópios de erliquiose

\author{
Ana Sílvia Dagnone ${ }^{1}$; Alda Izabel de Souza ${ }^{2}$ : Marcos Rogério André ${ }^{\text {; }}$ Rosangela Zacarias Machado ${ }^{1 *}$ \\ ${ }^{1}$ Universidade Estadual Paulista - UNESP \\ ${ }^{2}$ Universidade para o Desenvolvimento do Estado e da Regiáo do Pantanal - UNIDERP
}

Received May 5, 2009

Accepted July 20, 2009

\begin{abstract}
Ehrlichioses are important emerging zoonotic tick-borne diseases that can affect both animals and humans. Clinical manifestations of ehrlichiosis caused by different members of Anaplasmataceae in dogs are similar to each other and to other diseases showing systemic manifestation. The observation of inclusions in white blood cells and in platelets cannot be used to confirm the Anaplasmataceae etiologic agent of the disease. In this work we assessed the presence of Anaplasmataceae agents in 51 dogs from two different cities (Jaboticabal and Campo Grande) showing clinical and microscopical diagnosis of ehrlichiosis, by using molecular techniques. Anaplasmataceae DNA were amplified in 46/51 (90.2\%) of the blood samples; 22 (40\%) samples from Jaboticabal and 10 (18.2\%) from Campo Grande were positive for $E$. canis $\mathrm{nPCR}$. Anaplasma platys DNA was amplified in 2 samples from Jaboticabal and in 11 from Campo Grande. Phylogenetic analysis of $E$. canis and A. platys DNA confirmed the infection agent and showed that PCR is the most reliable method to diagnose ehrlichial infection.
\end{abstract}

Keywords: Dogs, Ehrlichia canis, Anaplasma platys, PCR, Brazil.

\section{Resumo}

Erliquioses são importantes enfermidades emergentes transmitidas por carrapatos que podem afetar os animais e o homem. Em cães, as manifestações clínicas da erliquiose causada por diferentes membros da Família Anaplasmataceae são similares entre si e entre outras enfermidades de manifestação sistêmica. A observação de inclusões em leucócitos e plaquetas não pode ser utilizada para diagnosticar o agente etiológico pertencente à Família Anaplasmataceae. O presente trabalho objetivou detectar, por meio de técnicas moleculares, a presença de agentes da Família Anaplasmataceae em 51 cães de duas diferentes cidades (Jaboticabal, SP e Campo Grande, MS) apresentando sinais clínicos e microscópios sugestivos de erliquiose. DNA de agentes da Família Anaplasmataceae foi amplificado em 46/51 (90,2\%) das amostras de sangue; 22 (40\%) amostras de Jaboticabal e 10 (18,2\%) amostras de Campo Grande foram positivas na nested PCR para E. canis. DNA de Anaplasma platys foi amplificado em duas amostras de Jaboticabal e em 11 de Campo Grande. Análise filogenética dos DNAs de E. canis e A. platys das amostras confirmou o agente etiológico e mostrou que a PCR é o método mais confiável no diagnóstico das infecçôes por agentes da Família Anaplasmataceae.

Palavras-chave: Cães, Ehrlichia canis, Anaplasma platys, PCR, Brasil. 


\section{Introduction}

Ehrlichioses are important emerging zoonotic tick-borne diseases that can affect both animals and humans (INOKUMA et al., 2001). Depending on the bacterial species, they can infect granulocytes, platelets, endothelial cells, monocytes, macrophages, red blood cells, and cells of invertebrates. The bacteria reside within the host cell, inside inclusion bodies (morulae) that provide a hospitable environment for their survival.

The Canidae can be infected by several Anaplasmataceae agents (DUMLER et al., 2001) such as Ehrlichia canis, Ehrlichia ewingii, Ehrlichia chaffeensis, Anaplasma platys, Anaplasma phagocytophilum, Neorickettsia risticii (INOKUMA et al., 2001) and N. helminthoeca (HEADLEY et al., 2006).

Co-infections with more than one ehrlichiosis agent have been reported in dogs (BREITSCHWERDT et al., 1998; KORDICK et al., 1999). The clinical signs of ehrlichiosis caused by E. canis are similar to those caused by other Anaplasmataceae species and are characterized by fever, anorexia, emaciation, hepatomegaly, splenomegaly, lymphadenopathy, cardiac and respiratory disturbance, and ocular alterations (BREITSCHWERDT et al., 1998; CASTRO et al., 2004; NAKAGHI et al., 2008). Additionally, Anaplasmataceae agents can cause diseases in humans (WALKER and DUMLER, 1996). In Brazil, suspicious cases have been already reported in Minas Gerais State in patients presenting suggestive clinical signs and positive serology for $E$. chaffeensis (CALIC et al., 2004; COSTA et al., 2005; COSTA et al., 2006). Thus, a definitive etiologic diagnostic method for diagnosis in dogs is necessary.

Although ehrlichiosis and anaplasmosis are described as prevalent in some regions of Brazil, this prevalence is based mostly on diagnosis that relies on clinical sign and haematological abnormalities, and on microscopic examination of peripheral blood and serology only (OLIVEIRA et al., 2000; LABARTHE et al., 2003; SOARES et al., 2006; TRAPP et al., 2006; COSTA Jr. et al., 2007; CARLOS et al., 2007; AGUIAR et al., 2007; SAITO et al., 2008; OLIVEIRA et al., 2008). As it is known, serological tests are not able to differentiate infections caused by various members of the Anaplasmataceae family because organisms sharing common antigens may generate cross-reactions (WANER et al., 2001). Thus, diagnoses made with these methods are often ambiguous and may fail in identifying the species of the causing agent (WANER et al., 2001).

Molecular diagnostic methods allow direct detection of these etiologic agents and sequence analysis facilitates their comparison to geographically diverse strains. To our knowledge, genetic and phylogenetic information about Anaplasmataceae agents in Brazil is limited (DAGNONE et al., 2003; BULLA et al., 2004; DE PAIVA DINIZ et al., 2007; NAKAGHI et al., 2008; MACIEIRA et al., 2005; HEADLEY et al., 2006; LABRUNA et al., 2007; AGUIAR et al., 2008; CARVALHO et al., 2008; SANTOS et al., 2009; CARDOZO et al., 2009; OLIVEIRA et al., 2009). Although E. canis DNA has been detected in dogs of many Brazilian states, phylogenetic analysis of Anaplasmataceae agents has not been performed in dogs from any part of the country.
Herein, we assessed the presence of Anaplasmataceae DNA in 51 dogs presenting clinical and optic microscopy diagnosis of ehrlichiosis. We also performed sequence alignment to indicate the identity of the parasite species infecting these animals.

\section{Materials and Methods}

Between 2003 and 2005, 51 blood samples from dogs with both clinical signals compatible with ehrlichiosis and the presence of intracitoplasmic inclusion bodies and/or morulae-like forms in white blood cells and platelets suggestive of infection by Anaplasmataceae agents, were collected for molecular analysis. A total of 25 blood samples came from dogs admitted to the Veterinary Teaching Hospital at the Universidade Estadual Paulista (UNESP), city of Jaboticabal in São Paulo, and 26 from the Veterinary Teaching Hospital of the Universidade para o Desenvolvimento do Estado e da Região do Pantanal (UNIDERP), city of Campo Grande, Mato Grosso do Sul, both in Brazil. A sample of $10 \mathrm{~mL}$ of blood was obtained from each dog aseptically by jugular venipuncture. Microscopic examination of buffy coat smears stained with Giemsa was performed. EDTA blood samples were then stored and frozen at $-20{ }^{\circ} \mathrm{C}$ until molecular analysis.

DNA was extracted from $200 \mu \mathrm{L}$ of whole blood using the QIAamp DNA Blood Mini kit (QIAGEN, Valentia, California, USA) according to the manufacturer's instructions. Each sample of extracted DNA was used as a template in $50 \mu \mathrm{L}$ reaction mixtures containing 10X PCR buffer, $1.5 \mathrm{mM} \mathrm{MgCl}_{2}, 10 \mathrm{mM}$ deoxynucleotide triphosphate (dNTPs) mixture, and DNA Taq Polymerase (Invitrogen, Carlsbad, California, USA) for genus and species-specific primers for Ehrlichia canis, E. chaffeensis (MURPHY et al., 1998; KOCAN et al., 2000), E. ewingii (PERSING, 1996), Anaplasma phagocytophilum (MASSUNG et al., 1998), and Neorickettsia risticii (CHAE et al., 2003), in a nested PCR assay based on 16SrRNA gene. Furthermore, a PCR based on $A$. phagocytophilum msp-2 gene (CASPERSEN et al., 2002) and a Anaplasma platys-specific PCR (INOKUMA et al., 2001) were performed when positive $A$. phagocytophilum nested PCR was found. In each set of amplifications, both positive and negative controls were included. Ehrlichia canis DNA positive controls were obtained from dogs experimentally infected with Jaboticabal strain E. canis (CASTRO el al., 2004). Positive control DNA for E. chaffeensis, A. phagocytophilum, and $N$. risticci were provided by Dr. J. Stephen Dumler at the Johns Hopkins Medical Institution, Baltimore, USA. Blood from a dog naturally infected with $A$. platys from Campo Grande was used as a positive control for this agent. A negative dog blood sample was used as a negative control. For samples that were positive for Ehrlichia spp. and Anaplasma spp., another PCR also based on the 16S rRNA (UNVER et al., 2001) was performed. The PCR and nested PCR amplifications were performed in a Gradient Cycler (Perkin-Elmer ${ }^{\mathrm{TM}}$ model PT-200).

PCR amplicons were ligated into pGEM-T Easy (Promega) Vector followed by transformation of DH10B Escherichia coli using the pGEM cloning kit (Madison, Wisconsin, USA), according to manufacturer's instructions. The resulting clones underwent blue/white colony screening. Plasmid DNA of positive clones 
was isolated by the Alcaline Lysis Method (SAMBROOK et al., 2001) and submitted for sequence determination (ABI Prism 310 Genetic Analyser - Applied Biosystem/Perkin Elmer [Foster City, California, USA]). Consensus sequences were obtained using the CAP3 program (http://mobyle.pasteur.fr/cgi-bin/MobylePortal/ portal.py) for subsequent phylogenetic analysis and blasted against GenBank sequences. The CLUSTAL W (THOMPSON et al., 1997) and MEGA (KUMAR et al., 2001) programs were used for alignment and phylogenetic analysis, respectively. The distance neighbor-joining method was used to build the phylogenetic tree (SAITOU; NEI, 1987) using the Kimura-2-parameter model. The bootstrap test with 1000 replications was replied to estimate the confidence of branching patterns of the neighbor-joining tree (FELSENSTEIN, 1985).

\section{Results}

A wide variety of shapes (point, circles, oval) and sizes were found as inclusions in the blood smears of dogs (Figure 1). The small (point-shaped) bodies, circle-shaped forms, and berry-shaped forms are suspected to be elementary bodies, initial bodies, and morulae, respectively. The coloration ranged from dark basophilic (the majority of inclusions) to acidophilic.

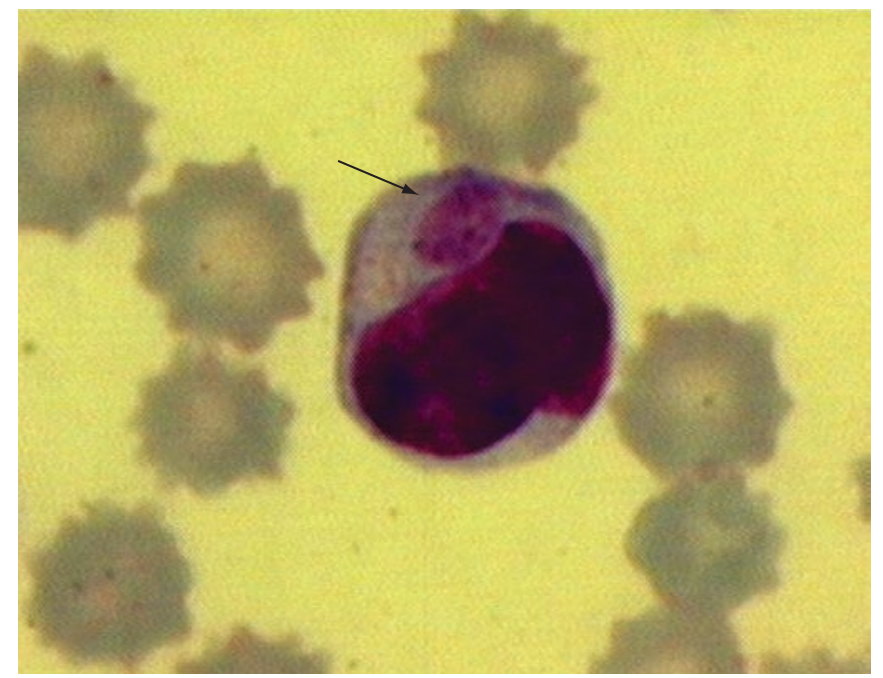

Inclusions in platelets, isolated or paired (less frequent), showed purple coloration.

Anaplasmataceae DNA was amplified in $46 / 51(90.2 \%)$ of the blood samples. A total of $22(40 \%)$ and $10(18.2 \%)$ samples from Jaboticabal and Campo Grande, respectively, were positive for $E$. canis by nested PCR. Anaplasma platys DNA was amplified in 2 samples from Jaboticabal and in 11 from Campo Grande. The primer pair for $A$. phagocytophilum msp2-gene (CASPERSEN et al., 2002) was also used because all the 13 samples positive for $A$. platys were expected to be also positive for the A. phagocytophilum 16SrRNA nested PCR (MASSSUNG et al., 1998), as they belong to the same genogroup. Co-infection with $E$. canis and A. platys was observed in 2 dogs from the Jaboticabal samples. None of the studied samples were positive for the other Anaplasmataceae agents tested. A total of $11(20 \%)$ samples were negative for all agents tested.

Interestingly, in three samples showing inclusion in platelets, two were positive for $E$. canis only, and one for A. platys only. Additionally, two dogs showed co-infection with $E$. canis and $A$. platys by PCR but no inclusions were seen in platelets. Inclusions in monocytes and in monocytes and platelets were seen, respectively, in one and two $E$. canis PCR-negative animals. Nine dogs with inclusions in platelets were $A$. platys PCR negative (Table 1).

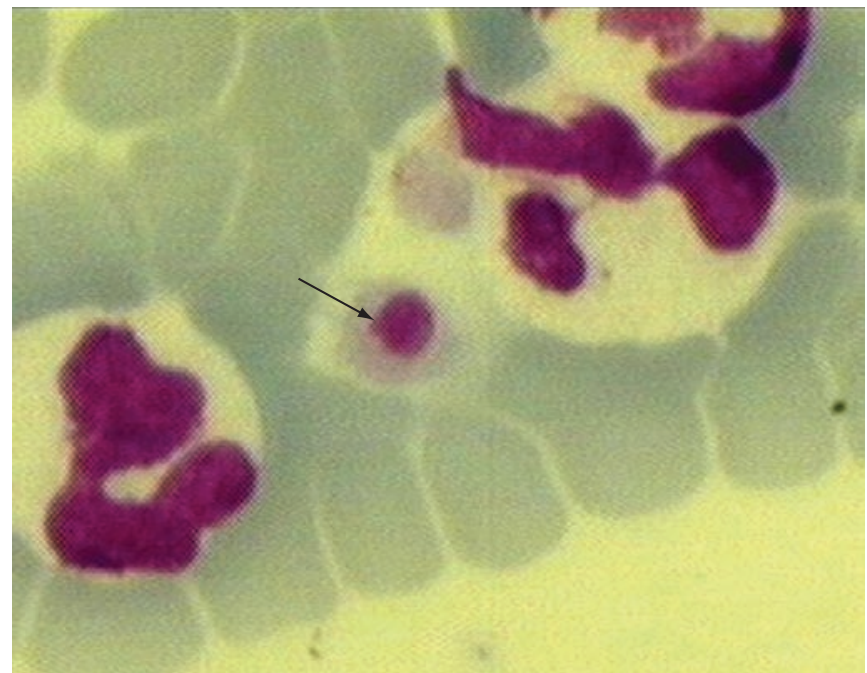

Figure 1. Canine blood smears showing inclusions bodies and morulae-like forms (arrows) from E. canis (A) and A. platys (B) PCR positive samples. Optic microscopy, Giemsa stained. Size: 1000×.

Table 1. Association between results of $E$. canis nested PCR, A. platys PCR, and optic microscopy of blood smears of dogs with suggestive clinical signs in Jaboticabal (SP) and Campo Grande (MS).

\begin{tabular}{lccc}
\hline \multicolumn{1}{c}{ Inclusions } & Number of animals & E. canis PCR +/- & A. platys PCR +/- \\
\hline Monocytes & 27 & $26 / 1$ & $2^{*} / 25$ \\
Platelets & 19 & $3 / 16$ & $10 / 9$ \\
Monocytes/Linfocytes & 1 & $1 / 0$ & $0 / 1$ \\
Monocytes/Platelets & 4 & $2 / 2$ & $2 / 2$ \\
Total & 51 & $32 / 19$ & $14 / 37$ \\
\hline
\end{tabular}

*co-infection with E. canis and A. platys. 
The sequences obtained for a previous positive E. canis-specific nested PCR that were submitted to a PCR with 750F/EC3 primers, were closely related to E. canis from Spain (Accession number AY 394465) and presented an identity percentage between 94.82 and $99.67 \%$, as isolates from different animals may vary. Previous positive samples for $A$. platys-specific PCR that were also submitted to PCR with $750 \mathrm{~F} / \mathrm{EC} 3$ and gE3a/gE10R primers, were closely related to $A$. platys from Venezuela (Accession number AF 399917) and Spain (Accession number AY 53806) and presented an identity of 99.69 and $99.37 \%$, and 97.63 and $97.87 \%$, respectively.

A representative E. canis isolate (Access number DQ401044) from Brazilian dogs clustered together with other Ehrlichia spp., such E. canis obtained from dogs from Spain, China, and Venezuela (Figure 2). Therefore, a representative $A$. platys (Access number DQ401045) from sampled dogs clustered together with other Anaplasma spp. including $A$. platys of dogs from Spain, Venezuela, United States, Japan, China, France, and Thailand (Figure 2).

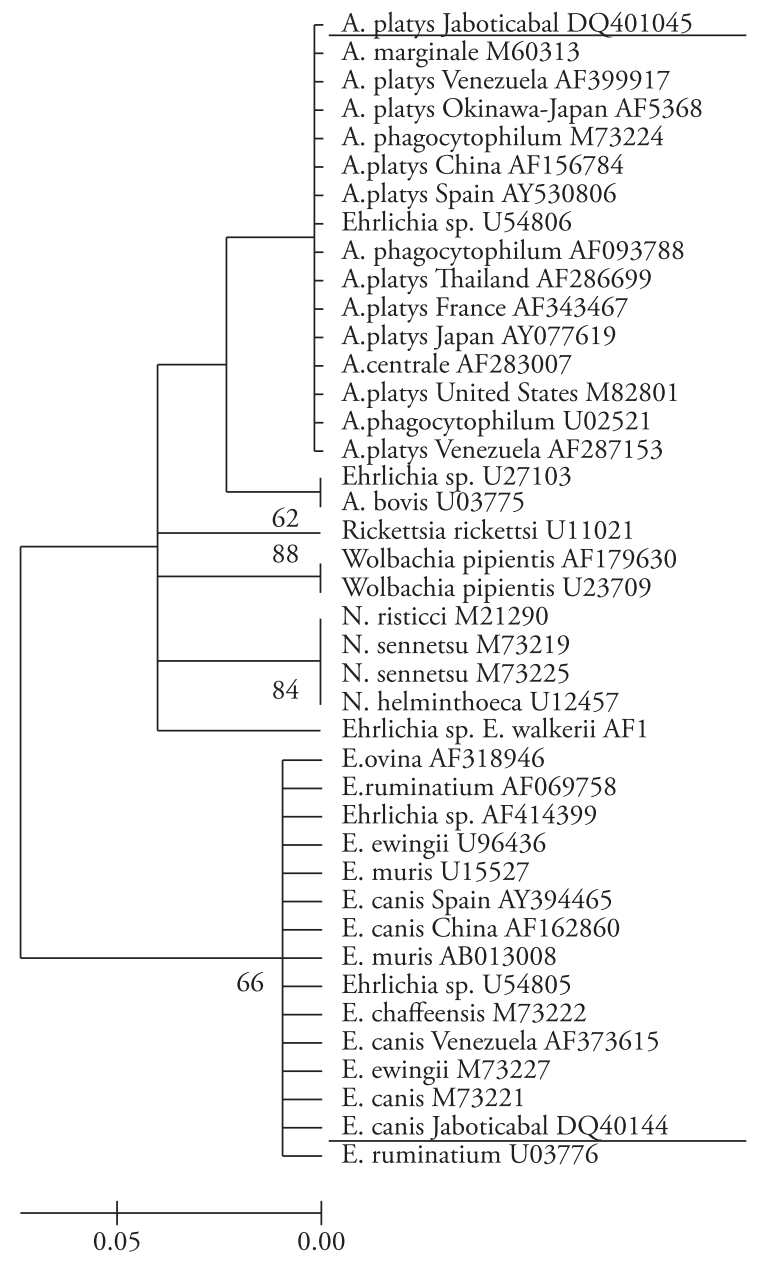

Figure 2. Phylogenetic Dendogram (Phylogram) showing relationship among a representative sequence of $A$. platys and $E$. canis from Brazilian sequences (sequences are underlined) and several GenBank sequences, according to their 16SrRNA partial gene sequence. Neighbor-joining algorithm with 1,000 bootstrap replicates is presented.

\section{Discussion}

Our results suggest that inclusions could help the diagnosis of Anaplasmataceae acute infections. However, the diversity found in shape, size, color, and localization of these inclusions requires caution when identifying the infecting species, and thus, should be followed by other diagnostic methods such as serology and molecular techniques. Moreover, canine monocytic ehrlichiosis in chronic stages could have polyclonal proliferation of lymphocytes, showing proeminent azurophilic granules ranging from 0.5 to $1.0 \mu \mathrm{m}$ in diameter. These findings should also be used to differentiate ehrlichiosis from lymphocytic proliferative disorders of neoplastic origin and other hemoparasites and unknown inclusions in the cells (HEEB et al., 2003). Moreover, morulae should be differentiated from inclusions present in severe bacterial infections (Döhle bodies), inflammation, auto-immune diseases, viral infection (distemper), and severe tissue destruction (SCHALM et al., 2000). In cases of canine granulocytic ehrlichiosis (CGE) (caused by E. ewingii or A. phagocytophilum), morulae are not differentiated by optic microscopy (PREOZI and COHN, 2002). On the other hand, when dog blood samples with suggestive symptoms of ehrlichiosis, but with no morulae detected in blood smears, were submitted to molecular techniques, a negative result was obtained (ALLSOPP and ALLSOPP, 2001; DAGNONE et al., 2003). Low rickettsiemia can also lead to negative results by cytology and PCR (DU PLESSIS et al., 1990).

In Brazil, E. canis DNA was tested by PCR for the first time in 2003, when 28 of the 129 (21.7\%) anemic, thrombocytopenic, or tick-harboring dogs in University Veterinary Teaching Hospital in Londrina in Paraná were PCR positive (DAGNONE et al., 2003). Ehrlichia canis DNA was found in $53.33 \%$ of the dogs with suggestive signs of ehrlichiosis in Sáo Paulo State University Veterinary Teaching Hospital in Jaboticabal (NAKAGHI et al., 2008). Although $E$. canis infection is relatively common in the Jaboticabal region (OLIVEIRA et al., 2000; CASTRO et al., 2004; OLIVEIRA et al., 2008; NAKAGHI et al., 2008), this has been, so far, the first molecular evidence of Anaplasma platys infection in dogs from the Jaboticabal and Campo Grande regions.

A. platys DNA was detected in dogs of Ribeirão Preto, a city located near Jaboticabal (SANTOS et al., 2009). Ehrlichia canis DNA was detected in $82.2,66.3$, and $32 \%$ of thrombocytopenic dogs of Botucatu (BULLA et al., 2004), Ribeirão Preto (SANTOS et al., 2009), and Rio de Janeiro (MACIEIRA et al., 2005), respectively. Also, E. canis DNA was detected in $78 \%$ of the sick dogs with clinicopathological abnormalities consistent with tick-borne infections (DINIZ et al., 2008).

In our study, co-infections of $E$. canis and $A$. platys were observed in two dogs from Jaboticabal. Cases of co-infection are often found due to the common tick vector of Brazilian dogs, Rhipicephalus sanguineus (OYAFUSO et al., 2002; DAGNONE et al., 2003; NAKAGHI et al., 2008; OLIVEIRA et al., 2008), which can transmit both agents (DANTAS-TORRES, 2008). Cases of co-infection with three Anaplasmataceae agents (E. canis, A. platys, and $A$. phagocytophilum) in dogs were documented in dogs from Thailand and from Venezuela (SUKASAWAT et al., 2001) and from the United States (E. canis, E ewingii, and A. phagocytophilum) 
(BREITSCHWERDT et al., 1998). The negative PCR result found in our study for the other Anaplasmataceae agents may be explained by the lack of competent vectors for these bacteria in the region where the study was conducted.

In this study we were able to show that inclusion bodies and morulae-like forms found in white blood cells and platelets should be investigated with caution to avoid mistakes in diagnoses of canine ehrlichiosis and anaplasmosis, even though suggestive clinical signs of these diseases may be present.

The present work shows that the direct detection of citoplasmatic inclusions in blood smears can help in the diagnosis of acute infections caused by Anaplasmataceae agents when applied cautiously and in association with molecular and serological techniques.

The Polymerase Chain Reaction and the molecular characterization of $E$. canis and $A$. platys DNA by phylogenetic analysis confirmed the infection by these agents in Brazilian dogs, and showed that this is the most reliable method to confirm an ehrlichial infection presenting inclusions in leucocytes and platelets.

\section{Acknowledgments}

The authors would like to thank Dr. J. Stephen Dumler, from the Johns Hopkins Medical Institution, Baltimore, MD, USA, for the Ehrlichia chaffeensis, Anaplasma phagocytophilum, and Neorickettsia risticii DNA positive controls; Dra. Alda Izabel Souza from Universidade para o Desenvolvimento do Estado e da Região do Pantanal (UNIDERP), Mato Grosso do Sul, Brazil, for the Anaplasma platys DNA positive control; and the Coordenação de Aperfeiçoamento de Pessoal de Nível Superior (CAPES) for the fellowship.

We would like to thank Marcia Triunfol of Publicase for manuscript suggestions and review and Carol Ross of Hyperlife Editing for proofreading.

\section{References}

AGUIAR, D. M.; HAGIWARA, M. K.; LABRUNA, M. B. In vitro isolation and molecular characterization of an Ehrlichia canis strain from São Paulo, Brazil. Brazilian Journal of Microbiology, v. 39, n. 3, p. 489-493, 2008.

AGUIAR, D. M. et al. Serological diagnosis of canine monocytic ehrlichiosis with Brazilian antigen of Ehrlichia canis. Ciência Rural, v. 37, n. 3, p. 796-802, 2007.

ALLSOPP, M. T. E.; ALSOPP, B. A. Novel Ehrlichia genotype detected in dogs in South Africa. Journal of Clinical Microbiology, v. 39, n. 11, p. 4204-4207, 2001.

BREITSCHWERDT, E. B.; HEGARTY, B. C.; HANCOCK, S. I. Sequential evaluation of dogs naturally infected with Ehrlichia canis, Ehrlichia chaffeensis, Ehrlichia equi, Ehrlichia ewiingii, or Bartonella vinsonii. Journal of Clinical Microbiology, v. 36, n. 9, p. 2645-2651, 1998.

BULLA, C. et al. The relationship between the degree of thrombocytopenia and infection with Ehrlichia canis in an endemic area. Veterinary Research, v. 35, n. 1, p. 141-6, 2004.
CALIC, S. B. et al. Human Ehrlichiosis in Brazil: first suspect cases. The Brazilian Journal of Infectious Diseases, v. 8, n. 3, p. 259-262, 2004.

CARLOS, R. S. et al. Frequency of antibodies anti-Ehrlichia canis, Borrelia burgdorferi and Dirofilaria immitis antigens in dogs from microrregion Ilhéus - Itabuna, State of Bahia, Brazil. Revista Brasileira de Parasitologia Veterinária, v. 16, n. 3, p. 117-120, 2007.

CARDOZO, G. P. et al. Molecular characterization of two strains of Anaplasma platys in Brazil. Veterinary Records, v. 164, n. 11, p. 338-340, 2009.

CARVALHO, F. S. et al. Epidemiological and molecular study of Ehrlichia canis in dogs in Bahia, Brazil. Genetics and Molecular Research, v. 7, n. 3, p. 657-62, 2008.

CASPERSEN, K. et al. Genetic variability and stability of Anaplasma phagocytophila msp2 (p44). Infection and Immunity, v. 70, n. 3, p. 1230-1234, 2002.

CASTRO, M. B. et al. Experimental acute canine monocytic ehrlichiosis: clinicopathological and immunopathological findings. Veterinary Parasitology, v. 119, n. 1, p. 73-86, 2004.

CHAE, J. S. et al. Prevalence and sequence analyses of Neorickettsia risticii. Annals of the New York Academy of Sciences, v. 990, n. 1, p. 248-256, 2003.

COSTA Jr., L. M. Sero-prevalence and risk indicators for canine ehrlichiosis in three rural areas of Brazil. Veterinary Journal, v. 174, n. 3, p. 673-6, 2007.

COSTA, P. S. G.; BRIGATTE, M. E.; GRECO, D. B. Antibodies to Rickettsia rickettsii, Rickettsia typhi, Coxiella burnetti, Bartonella henselae, Bartonella quintana, and Ehrlichia chaffeensis among healthy population in Minas Gerais, Brazil. Memórias do Instituto Oswaldo Cruz, v. 100, n. 8, p. $853-859,2005$.

COSTA, P. S. G. et al. More about Human Monocytotropic Ehrlichiosis in Brazil: serological evidence of new nine cases. The Brazilian Journal of Infectious Diseases, v. 10, n. 1, p. 7-10, 2006.

DAGNONE, A. S. et al. Ehrlichiosis in anemic, thrombocytopenic, or tick-infested dogs from a hospital population in South Brazil. Veterinary Parasitology, v. 117, n. 4, p. 285-290, 2003.

DANTAS-TORRES, F. Canine vector-borne diseases in Brazil. Veterinary Parasitology, v. 1, n. 1, p. 25, 2008.

DE PAIVA DINIZ, P. P. et al. Surveillance for zoonotic vector-borne infections using sick dogs from southeastern Brazil. Vector Borne and Zoonotic Diseases, v. 7, n. 4, p. 689-697, 2007.

DINIZ, P. P. et al. Serum cardiac troponin I concentration in dogs with ehrlichiosis. Journal of Veterinary Internal Medicine, v. 22, n. 5, p.1136-1143, 2008.

DUMLER, J. S. et al. Reorganization of genera in the families Rickettsiaceae and Anaplasmataceae in the order Rickettsiales: identification of some species of Ehrlichia with Anaplasma, Cowdria with Ehrlichia and Ehrlichia with Neorickettsia, descriptions of six new species combinations and designation of Ehrlichia equi and 'HGE agent' as subjective synonyms of Ehrlichia phagocytophila. International Journal of Systematic and Evolutionary Microbiology, v. 51, p. 2145-2165, 2001.

DU PLESSIS, J. L. et al. Concurrent babesiosis and ehrlichiosis in the dog: blood smear examination supplemented by the indirect fluorescent antibody test, using Cowdria ruminantium as antigen. Onderspoort Journal of Veterinary Research, v. 57, n. 3, p. 151-155, 1990. 
FELSENSTEIN, J. Confidence limits on phylogenies: an approach using the bootstrap. Evolution, v. 39, n. 4, p. 783-791, 1985.

HEADLEY, S. A. et al. Neorickettsia helminthoeca in dog, Brazil. Emerging Infectious Diseases, v. 12, n. 8, p. 1303-1304, 2006.

HEEB, H. L. et al. Large granular lymphocytosis, lymphocyte subset inversion, thrombocytopenia, dysproteinemia, and positive Ehrlichia serology in a dog. Journal of the American Animal Hospital Association, v. 39, n. 4, p. 379-384, 2003.

INOKUMA, H. et al. Detection of ehrlichial infection by PCR in dogs from Yamaguchi and Okinawa Prefectures, Japan. The Journal of Veterinary Medical Science, v. 63, n. 7, p. 815-817, 2001.

KOCAN, A. et al. Naturally occurring Ehrlichia chaffeensis infection in coyotes from Oklahoma. Emerging Infectious Diseases, v. 6, n. 5, p. 477-480, 2000.

KORDICK, S. K. et al. Coinfection with multiple tick-borne pathogens in a Walker Hound Kennel in North Carolina. Journal of Clinical Microbiology, v. 37, n. 8, p. 2631-2638, 1999.

KUMAR, S. et al. Mega2: Molecular evolutionary genetics analysis software. Bioinformatics, v. 17, n. 12, p. 1244-1245, 2001.

LABARTHE, N. et al. Serologic prevalence of Dirofilaria immitis, Ehrlichia canis, and Borrelia burgdorferi infections in Brazil. Veterinary Therapeutics, v. 4, n. 1, p. 67-75, 2003.

LABRUNA, M. B. et al. A preliminary investigation of Ehrlichia species in ticks, humans, dogs, and capybaras from Brazil. Veterinary Parasitology, v. 143, n. 2, p. 189-95, 2007.

MACIEIRA, D. B. et al. Prevalence of Ehrlichia canis infection in thrombocytopenic dogs from Rio de Janeiro, Brazil. Veterinary Clinical Pathology, v. 34, n. 1, p.44-48, 2005.

MASSUNG, R. et al. Nested PCR assay for detection of Granulocytic Ehrlichiae. Journal of Clinical Microbiology, v. 36, n. 4, p. 1090-1095, 1998.

MURPHY, G. L. et al. A molecular and serologic survey of Ehrlichia canis, E. chaffeensis, and E. ewingii in dogs and ticks from Oklahoma. Veterinary Parasitology, v. 79, n. 4, p. 325-339, 1998.

NAKAGHI, A. C. H. et al. Clinical, hematological, serological and molecular survey of canine ehrlichiosis. Ciência Rural, v. 38, n. 3, p. $776-770,2008$

OLIVEIRA, T. M. et al. A study of cross-reactivity in serum samples from dogs positive for Leishmania sp., Babesia canis and Ehrlichia canis in enzyme-linked immunosorbent assay and indirect fluorescent antibody test. Revista Brasileira de Parasitologia Veterinária, v. 17, n. 1, p. 7-11, 2008.

OLIVEIRA, D. et al. Detecção de anticorpos anti-Ehrlichia canis em cães naturalmente infectados, através do "DOT-ELISA". Revista Brasileira de Parasitologia Veterinária, v. 9, n. 1, p. 1- 6, 2000.

OLIVEIRA, L. et al. First report of Ehrlichia ewingii detected by molecular investigation in dogs from Brazil. Clinical Microbiology and Infection, 2009 (in press).
OYAFUSO, M. K. et al. Characterization of ticks infecting dogs in a hospital population in North Paraná, Brazil. Semina- Ciências Agrárias, v. 23, n. 1, p. 87-90, 2002.

PERSING, D. H. PCR Protocols for Emerging Infectious Diseases. A supplement to Diagnostic Molecular Microbiology: Principles and Applications. Washington: ASM Press, 1996.

PREOZI, D. E.; COHN, L. A. The increasingly complicated story of Ehrlichia. Compendium on Continuing Education for the Practicing Veterinarian, v. 24, n. 4, p. 277-288, 2002.

SAMBROOK, J.; RUSSEL, D. W. Molecular cloning: a laboratory manual. [S.I.]: Cold Spring Harbor Laboratory Press, 2001. 999 p.

SAITO, T. B. et al. Canine infection by rickettsiae and ehrlichieae in southern Brazil. American Journal of Tropical Medicine and Hygiene, v. 79, n. 1, p. 102-8, 2008.

SCHALM, O. W. Schalm's Veterinary Hematology. In: FELDMAN, J. G. Z.; Jain, N. C. Philadelphia: Lippincott Williams \& Wilkins, 2000. 1344 p.

SAITOU, N.; NEI, M. The neighbor-joining method: a new method for reconstructing phylogenetic trees. Molecular Biology and Evolution, v. 4, n. 4, p. 406-425, 1987.

SANTOS, F. et al. Molecular evaluation of the incidence of Ehrlichia canis, Anaplasma platys and Babesia spp. in dogs from Ribeirão Preto, Brazil. Veterinary Journal, v. 179, n. 1, p. 145-148, 2009.

SOARES, A. O. et al. Evaluation of ectoparasites and hemoparasites in dogs kept in apartments and houses with yards in the city of Juiz de Fora, Minas Gerais, Brazil. Revista Brasileira de Parasitologia Veterinária, v. 15 , n. 1, p. 13-6, 2006.

SUKASAWAT, J. et al. Coinfection with three Ehrlichia species in dogs from Thailand and Venezuela with emphasis on consideration of $16 \mathrm{~S}$ ribossomal DNA secondary structure. Journal of Clinical Microbiology, v. 39, n. 1, p. 90-93, 2001.

TRAPP, S. M. et al. Seroepidemiology of canine babesiosis and ehrlichiosis in a hospital population. Veterinary Parasitology, v. 140, n. 3-4, p. 223-230, 2006.

THOMPSON, J. D. et al. The Clustal X windows interface: flexible strategies for multiple sequence alignment aided by quality analysis tools. Nucleic Acids Research, v. 25, n. 24, p. 4876-4882, 1997.

WALKER, D. H.; DUMLER, J. S. Emergence of the ehrlichiosis as human health problems. Emerging Infectious Diseases, v. 2, n. 1, p. 18-25, 1996.

WANER, T. et al. Significance of serological testing for ehrlichial diseases in dogs with special emphasis on the diagnosis of canine monocytic ehrlichiosis caused by Ehrlichia canis. Veterinary Parasitology, v. 95, n. 1, p. 1-15, 2001.

UNVER, A. et al. Molecular and antigenic comparasion of Ehrlichia canis isolates from dogs, ticks, and a human in Venezuela. Journal of Clinical Microbiology, v. 39, n. 8, p. 2788-2793, 2001. 